\section{Primate lab faces closure threat over mistreatment charge}

Quirin Schiermeier, Munich

Germany's largest primate laboratory is in danger of losing its licence after a television exposé alleged mistreatment of monkeys there.

Last spring, the British Union for the Abolition of Vivisection sent film-maker and investigative journalist Friedrich Mülln undercover into the Münster laboratory of Covance, a multinational

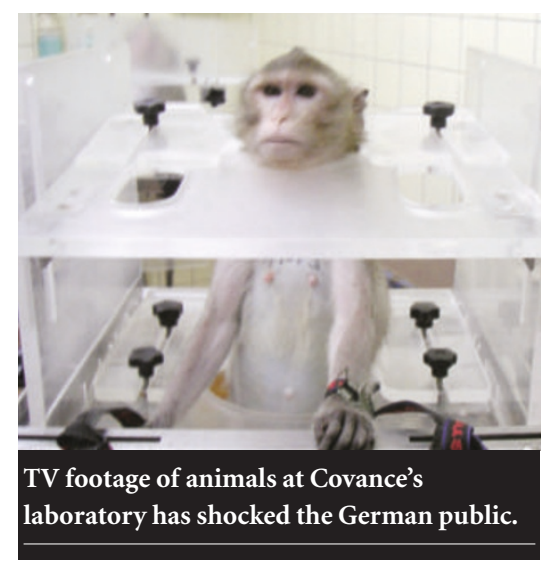

company that carries out contract research for the pharmaceutical industry. Over five months he secretly filmed staff seemingly tormenting macaques and rhesus monkeys.

The footage, shown last month on German public television, shows animal keepers apparently dancing with semianaesthetized macaques, shaking the monkeys' heads in time to music.

Bärbel Höhn, environment minister of North Rhine-Westphalia, has asked public prosecutors to investigate the "obvious unreliability" of Covance's staff. If the programme's accusations are justified, the laboratory's licence to keep primates will be withdrawn, she says.

"We are convinced that our staff have not violated animal-protection laws," says Friedhelm Vogel, managing director of the Münster lab. "The scenes are authentic. However, they have been edited and commentary added such that the impression arises that monkeys were systematically mistreated. This is not true." Covance has said that it will cooperate fully with the authorities and take any action required.

"It does appear as if animals were at least treated in a degrading way," says Ivar Aune, spokesman for the German research lobby group Society for Health and Research. But he adds that "monkeys are dangerous animals and precautions have to be taken".

\section{Ecologists hit out at plan to export Argentinian parrots}

Rex Dalton, San Diego

An application from Argentina to export parrots as pets to the United States has sent feathers flying among ecologists, some of whom say it would deplete populations in the wild.

If the application is accepted, Argentina will become the first country to export wild birds for the US pet trade since a tough law on imports was enacted in 1992 to prevent species being wiped out by commercial trappers.

Government biologists in Argentina have fashioned "a sustainable-use management plan" that they say will allow limited collecting of the blue-fronted Amazon parrot, Amazona aestiva - with part of the money from sales going towards maintaining the parrots' threatened forest habitat.

Such plans are seen as a way of preventing the extinction of animals and plants in countries where forest is being clear-cut. Argentina - South America's biggest exporter of wild birds - sends blue-fronted Amazons to Europe and elsewhere under its plan.

But Argentina's proposal, which the US Fish and Wildlife Service (FWS) sought comments on last August, has been criticized by about 100 ecologists and 30 conservation organizations around the world, who have lodged objections to it with the FWS.

The critics claim that there has been insufficient scientific study of the implications of harvesting blue-fronted Amazons, that inadequate resources are put aside to monitor the collecting and that the plan fails to address the possibility of exported parrots escaping to the wild and transmitting exotic diseases to native birds.
The blue-fronted Amazon is not endangered or threatened. But opponents of the application claim it could set off a rush of applications to export other species to the United States, potentially depleting wild-bird stocks in South America, Africa and Asia. "We are very concerned about the precedent this will set," says James Gilardi, director of the World Parrot Trust based in Cornwall, UK.

The Argentinian proposal is defended by tropical ecologist Susan Lieberman, director of environmental group the WWF's species programme in Surrey, UK. As a former official of the FWS, she was involved in drafting the 1992 legislation.

The Argentinian plan "is not a perfect situation", she says. "But they have made a valiant effort. I think the plan is tenable.” If it does not seem to be working, the plan can be suspended when it comes up for renewal in three years' time.

"The parrots are losing out to agriculture that removes habitat," says Ricardo Banchs, a biologist with Argentina's Sustainable Development and Environmental Secretariat. "There is no easy solution. We believe this is the only way to solve the problem."

Ecologist Enrique Bucher, an authority on the blue-fronted Amazon at the National University of Cordova in Argentina, is against the proposal. "We don't have a scientific way to manage these things," he says.

Michael Kreger of the FWS says that the agency is reviewing the comments received. "We want the Argentines to do this based on the best science," he says. "They aren't doing this to exploit the resource." A FWS decision is expected in the next few months.

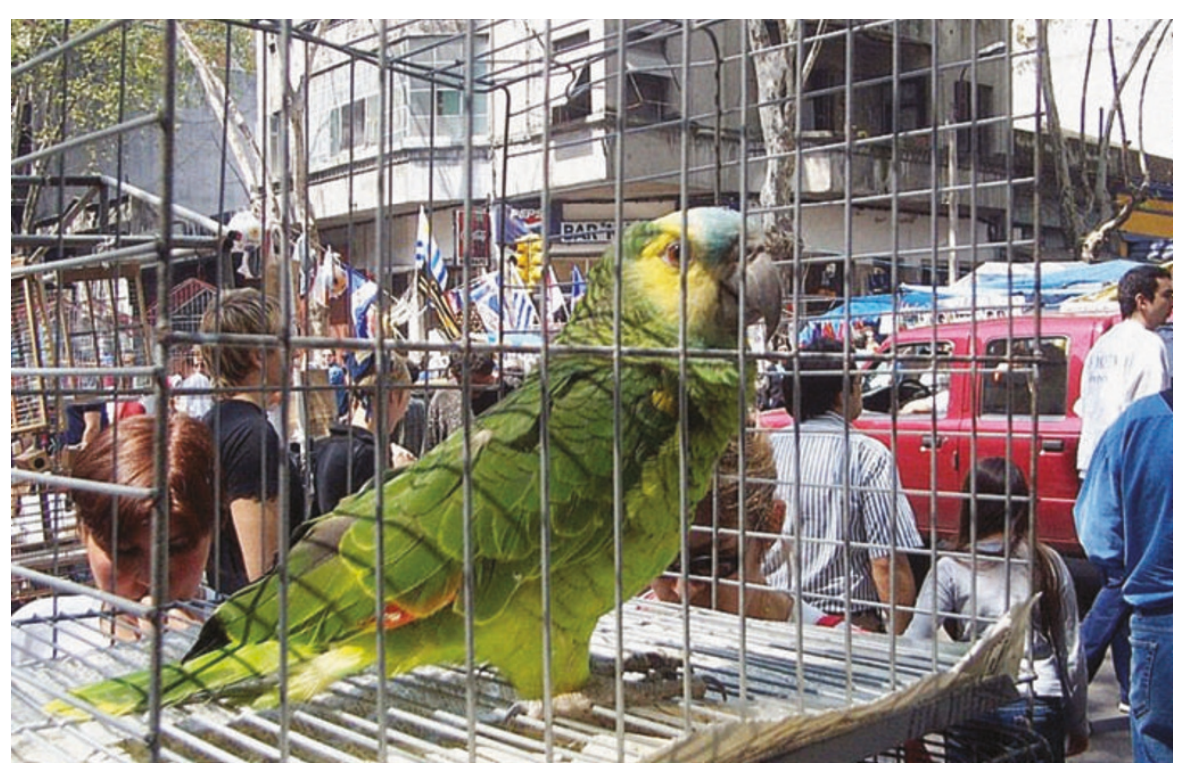

Sales talk: parrots are bought and sold in the street markets of South America. 